\title{
Evaluation of thyroid function abnormalities in sixty dogs naturally infected with Babesia canis
}

\author{
Nada Kučer ${ }^{1}$, Hana Marin², Jelena Gotić1, Josipa Kuleš ${ }^{1}$, Jurica Tršan'1, \\ Filip Kajin ${ }^{1}$, and Renata Barić Rafaj ${ }^{3 *}$
}

\author{
${ }^{I}$ Clinic for Internal Diseases, Faculty of Veterinary Medicine, University of Zagreb, Zagreb, Croatia \\ ${ }^{2}$ Veterinary Practice Nera, Zagreb, Croatia \\ ${ }^{3}$ Department of Chemistry and Biochemistry, Faculty of Veterinary Medicine, University of Zagreb, \\ Zagreb, Croatia
}

\section{KUČER, N., H. MARIN, J. GOTIĆ, J. KULEŠ, J. TRŠAN, F. KAJIN, R. BARIĆ RAFAJ: Evaluation of thyroid function abnormalities in sixty dogs naturally infected with Babesia canis. Vet. arhiv 89, 55-69, 2019.}

\section{ABSTRACT}

Canine babesiosis is world-wide tick-borne disease characterized by erythrocyte destruction, haemolysis and inflammatory response, with increased serum concentrations of positive acute phase proteins and a decrease in negative acute phase proteins. Some of the negative acute phase proteins function as carriers of thyroid hormones, so the goal of this study was to determine the non-thyroidal illness syndrome in dogs with babesiosis. The study included 60 dogs with babesiosis and 26 healthy dogs. Serum concentrations of thyroxine, thyrotropin and transthyretin were determined using ELISA methods, while albumin concentrations were measured using spectrophotometric methods. Statistical analysis of the data demonstrated a significant decrease in thyroxine, transthyretin and albumin in dogs with babesiosis, while thyrotropin concentrations were did not differ significantly in comparison with healthy dogs. The results obtained indicate the presence of a non-thyroidal illness. Decreased albumin and transthyretin probably represent one of the mechanisms which contribute to this syndrome in canine babesiosis.

Key words: dogs; babesiosis; nonthyroidal illness; transthyretin

\section{Introduction}

Babesiosis is a tick-borne disease of animals and occasionally humans, caused by intraerythrocytic protozoa of the genus Babesia. Dogs are among most commonly affected species. Canine babesiosis is presented world-wide, where B. canis infection

\footnotetext{
${ }^{*}$ Corresponding author:

Renata Barić Rafaj, PhD, Department of Chemistry and Biochemistry, Faculty of Veterinary Medicine, University of Zagreb, Heinzelova 55, 10000 Zagreb, Croatia, Phone+385 12390 301; E-mail: rrafaj@vef.hr
} 
occurs predominantly in Europe, B. rossi in South Africa, and B. vogeli and B. gibsoni occur widely in the New and Old World (SOLANO-GALLEGO and BANETH, 2011). In Croatia, infection is mostly caused by $B$. canis, although infection with $B$. vogeli, $T$. anne (B. microti-like) and B. gibsoni have also been proven (BECK et al., 2009).

For its life cycle babesia needs a host and a biological vector. Biological vectors which participate in the natural transmission of the babesia are ticks of the Family Ixodidae. Animals are infected while the tick sucks blood, whereby the injection of the sporozoits occurs via saliva through the skin. In the carrier host, the sporozoits adhere to the erythrocyte membrane and invade the cytoplasm where they form ring-shaped trophozoits. With the replication of the parasite in the erythrocyte, merozoites develop, which are pear-shaped and often come in pairs. With further replication, the parasite causes destruction of the erythrocyte and then they invade new red blood cells. Babesia spp. most often causes illness in young dogs, even though dogs of all ages can be infected. The incubation period varies between 10-21 days for B. Canis and B. Vogeli and 14-28 days for $B$. gibsoni. The intensity of the pathological changes depends on the kind of the babesia, the immunological status of the host, infections or diseases present, and age. The course of illness can be peracute, acute, chronic or subclinical (SCHOEMAN, 2009). Babesiosis in dogs manifests clinically in two forms: non-complicated, with signs mostly due to haemolysis, and the complicated form which occurs as a consequence of systemic inflammatory response syndrome (SIRS) and multiple organ dysfunction syndrome (MODS) (SELANEC et al., 2012).

Clinical signs consist of pale mucous membranes, depression, tachycardia, tachypnoea, anorexia, weakness, splenomegaly, pyrexia and haemoglobinuria. This presentation indicates the non-complicated form, while the complicated form of babesiosis also presents signs of dysfunction of one or more organ systems, i.e. disorder of the function of the central nervous system, occurrence of disseminated intravascular coagulation, immune mediated haemolytic anaemia, acute respiratory distress syndrome, rhabdomyolysis and acute liver or kidney damage. The complicated form results in a high mortality rate (LOBETTI, 2000; KIŠ, 2007; SCHOEMAN, 2009).

Inflammation in babesiosis. Infection of the macroorganism by a intraerythrocytic parasite from genus Babesia triggers an inflammatory response. This pathophysiological pattern has been proven experimentally in various test animals, including dogs that were infected with $B$. Canis. In a study conducted in 2009, SCHETTERS et al. concluded that splenectomy is the main risk factor in the development of a severe infection, regardless of the kind of Babesia. The spleen has an important role in the defence of the host and it is responsible for the removal of the infected erythrocytes from the bloodstream and the development of the immune response (SCHETTERS et al., 2009). 
During tissue damage, which can be caused by a variety of infectious, immunological, neoplastic, traumatic and other factors, the organism reacts by developing an acute phase response. This is part of the nonspecific inflammatory reaction of the organism, occurring quickly after tissue damage, in which pro-inflammatory cytokines are released. The most important of these cytokines are IL-6, IL-1 and TNF- $\alpha$. They have an effect on the hepatocytes and thus induce the increased or decreased synthesis of certain proteins in the acute phase (CERÓN et al., 2005). The acute phase response is characterized by numerous other systemic signs, such as fever, leucocytosis, increased cortisol levels in the blood, decreased concentrations of thyroxine, metabolic changes (lipolysis, gluconeogenesis and catabolism of muscles) and decreased concentrations of iron and zinc in the serum (CERÓN et al., 2005).

It is possible to determine the activation of an inflammatory response through protein values in the acute phase in dogs infected with babesia. Since this is a fast response which develops before specific immunity and clinical symptoms, we can regard it as one of the earliest signs of a pathological process or illness (CERÓN et al., 2005).

Thyroid gland. The thyroid is an endocrine gland affecting the function of almost all organs in the body. Thyroid hormones are responsible for controlling the concentration and functionality of numerous enzymes, thus affecting the metabolic processes of fat, carbohydrate, protein, vitamin, mineral utilization, the secretion and degradation of other hormones, as well as tissue response to other hormones. These actions are mediated by the binding of the thyroid hormone and thyroid hormone nuclear receptors, which subsequently activates gene transcription and leads to various forms of protein (enzyme) synthesis. The main thyroid hormones are thyroxine (T4), 3,5,3'-L-triiodothyronine (T3) and 3,3',5'-triiodothyironine (reverse T3). T3 is 3 to 10 times more active than $\mathrm{T} 4$, whereas reverse $\mathrm{T} 3$ is inactive. The thyroid excretes mostly $\mathrm{T} 4$ and only a small amount of the more efficient $\mathrm{T} 3$, so a considerable part of circulating $\mathrm{T} 3$ is derived by deiodination of T4 in the peripheral tissue (FELDMAN and NELSON, 2003).

The release of thyroid hormones is regulated by hypothalamus and pituitary gland (hypothalamus-pituitary-thyroid axis). The hypothalamus produces the thyrotropin releasing hormone (TRH) which stimulates the pituitary gland to excrete thyrotropin (the thyroid-stimulating hormone, TSH). Thyrotropin has a stimulating effect on thyroid hormone synthesis and secretion, and in addition, it stimulates the growth and function of the thyroid gland.

The feedback effect of an increased concentration of the thyroid hormone (in a free or unbound form) is the major mechanism regulating the further excretion of TSH and TRH (FELDMAN and NELSON, 2003).

Thyroid hormones circulate in the blood, mainly bound to plasma proteins. Thyroxine and $\mathrm{T} 3$ are insoluble lipophilic compounds. Their ability to circulate in the plasma 
depends on the possibility of binding to specific proteins, thyroxin-binding globulin (TBG) and thyroxin- binding prealbumin - transthyretin (TTR), and to albumins. TTR and TBG are acute phase proteins, and their concentrations may significantly decrease in various diseases. They provide a continuously available source of hormones, maintaining the free or active part of the hormone in a narrow range. TTR and albumins can also serve as hormone carriers in some tissues. (BIGLER, 1976; LARSSON et al., 1985, AFANDI et al., 2000)

Nonthyroidal illness syndrome. Nonthyroidal illness syndrome (NTIS), previously defined as euthyroid sick syndrome, is a general term describing changes in thyroid hormone concentrations during various acute and chronic diseases in patients that occur in the setting of a nonthyroidal illness. Therefore, the syndrome should not be considered as an isolated pathological manifestation, but as part of a coordinated disease response (FARWELL, 2008). Several different explanations can be found in the literature regarding the NTIS mechanism development.

The causes of non-thyroid illness syndrome may be numerous: changes in the hypothalamus-pituitary axis, changes in the binding of thyroid hormones to binding proteins, modification of the hormone's entry into the tissues, changes in thyroid hormone metabolism due to changes in intracellular dehydrogenase activity, and changes in the thyroid function receptor on the cell nucleus (WARNER and BECKETT, 2010). Although changes in thyroid hormone concentrations may represent adaptive processes in energy conservation by reducing the metabolism, some authors claim that systemic diseases may lead to central hypothyroidism (MYERS ADLER and WARTOFSKY, 2007).

This study covers several related aspects of babesiosis, including inflammatory response, thyroid function, and the possible mechanism of nonthyroidal illness syndrome development in canine babesiosis. The specific goal was to compare the T4, TSH, TTR and albumin concentrations between the control group of healthy dogs and babesiosisinfected dogs, and to investigate any possible association of thyroid hormone carrier concentrations with the development of nonthyroidal illness syndrome.

\section{Materials and methods}

Sixty client-owned dogs with babesiosis, and 26 healthy dogs (control group) were enrolled in the study. All researched dogs were patients at the Clinic for Internal Diseases, of the Faculty of Veterinary Medicine, University of Zagreb.

The investigated group was composed of dogs naturally infected with babesiosis. Diagnosis was established on the basis of clinical findings (fever, lethargy, anorexia, anaemia, macrohaematuria, and splenomegaly), and confirmed by microscope examination of Romanowsky-stained peripheral blood smears, with findings of Babesia 
spp. parasites within the infected erythrocytes. Excluding criteria were earlier diagnosis of hypothyroidism and any drug therapy in the preceding 3 months.

The control group was composed of dogs that were admitted for a regular health check that had normal clinical, haematology and biochemistry results.

Blood samples were taken from the cephalic vein into tubes containing EDTA as an anticoagulant, and tubes with no additives. Haematological analysis of blood samples containing EDTA was performed within 2 hours. Blood samples with no additives were centrifuged at $1500 \times \mathrm{g}$ for 10 minutes within 20 minutes after the blood was drawn. A routine biochemistry panel was done within two hours and the rest of serum was stored at $-70{ }^{\circ} \mathrm{C}$ for additional analysis.

Total T4, TSH and TTR were measured from the serum using a dog specific ELISA test (Holzel, Germany). Optical density was measured with the microplate reader on $450 \mathrm{~nm}$ (Biorad). Albumin concentration was measured by spectrophotometry using an Olympus automated chemistry analyser (Olympus, Germany).

Statistical analysis was performed with STATISTICA for Windows (StatSoft, Inc). A Kolmogornov-Smirnov test was used to test the equality of distribution. Student's t-test was used to compare data with normal distribution, and the Mann-Whitney $\mathrm{U}$ test to compare nonparametric data. The level of significance was set at $\mathrm{P}<0.05$.

\section{Results}

Serum concentrations of T4, TSH, TTR and albumin were determined in the group of healthy dogs (control group). Data were statistically analysed and the results are presented in Table1.

Table 1. T4, TSH, TTR and albumin serum concentration in control group of dogs

\begin{tabular}{|l|c|c|c|c|c|c|}
\hline Parameter & $\mathrm{N}$ & Mean & Median & Minimum & Maximum & SD \\
\hline $\mathrm{T}_{4} \mathrm{ng} / \mathrm{mL}$ & 25 & 43.71 & 43.55 & 24.95 & 58.21 & 7.72 \\
\hline $\mathrm{TSH} n \mathrm{ng} / \mathrm{mL}$ & 24 & 0.45 & 0.26 & 0.07 & 1.87 & 0.46 \\
\hline $\mathrm{TTR} n \mathrm{n} / \mathrm{mL}$ & 23 & 185.86 & 41.68 & 0.10 & 1324.64 & 307.35 \\
\hline ALB g/L & 26 & 32.27 & 32.00 & 27.00 & 39.00 & 2.39 \\
\hline
\end{tabular}

Concentrations of $36.9-50.2 \mathrm{ng} / \mathrm{mL}$ for T4, $0.14-1.27 \mathrm{ng} / \mathrm{mL}$ for TSH, $16-505 \mathrm{ng} / \mathrm{mL}$ for TTR and 31-34 g/L for albumin were set as reference values. The thyroid parameter reference value may be used as relevant in other similar cases when analytes are measured by immunoenzyme assay. 
N. Kučer et al.: Evaluation of thyroid function abnormalities in sixty dogs naturally infected with Babesia canis

Serum concentrations of the same parameters were also determined in the group of dogs suffering from babesiosis. The data are presented in Table 2.

Table 2. T4, TSH, TTR and albumin serum concentration in group of dogs with babesiosis

\begin{tabular}{|l|c|c|c|c|c|c|}
\hline Parameter & $\mathrm{N}$ & Mean & Median & Minimum & Maximum & SD \\
\hline $\mathrm{T}_{4} \mathrm{ng} / \mathrm{mL}$ & 60 & 23.48 & 20.32 & 11.19 & 48.08 & 9.08 \\
\hline TSH ng/mL & 60 & 0.57 & 0.32 & 0.01 & 10.75 & 1.37 \\
\hline TTR ng/mL & 60 & 83.82 & 16.38 & 0.10 & 577.47 & 140.38 \\
\hline ALB g/L & 60 & 26.40 & 26.00 & 16.00 & 36.00 & 4.51 \\
\hline
\end{tabular}

In the comparison of the investigated groups using the Mann-Whitney $U$ test there was statistical significant difference (if $\mathrm{P}<0.05$ ) between the dogs with babesiosis and the healthy dogs in T4, TTR and albumin concentrations, while TSH was not significantly changed. The level of significance is presented in Table 3.

Table 3. Level of statistical significance in difference of T4, TSH, TTR and albumin serum concentration in group of dogs with babesiosis compared to control group (P-value)

\begin{tabular}{|l|c|}
\hline Parameter & P-value \\
\hline $\mathrm{T}_{4}$ & 0.000000 \\
\hline TSH & 0.823663 \\
\hline TTR & 0.008185 \\
\hline ALB & 0.000000 \\
\hline
\end{tabular}

Comparisons of investigated parameters are presented in Figs. 1-4.

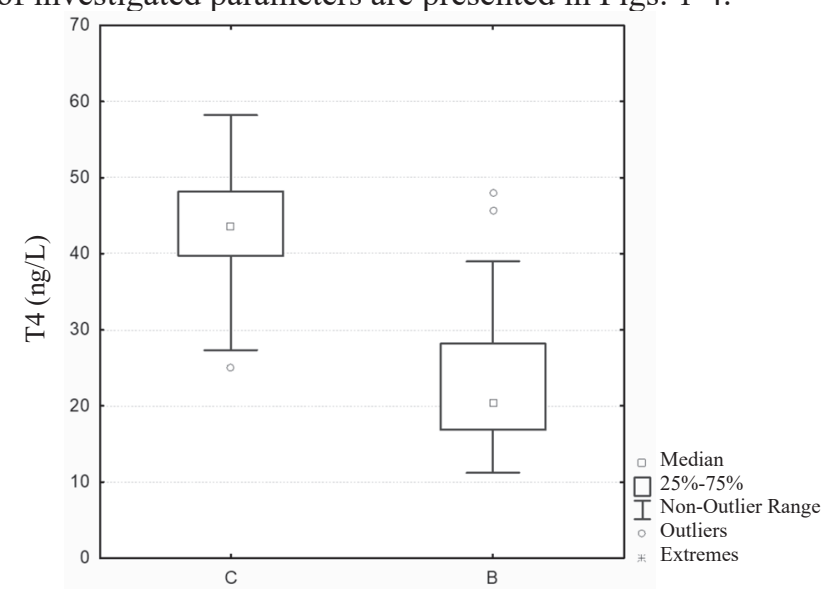

Fig. 1. Comparison of T4 concentration in control group (C) and group of dogs with babesiosis (B) 
N. Kučer et al.: Evaluation of thyroid function abnormalities in sixty dogs naturally infected with Babesia canis

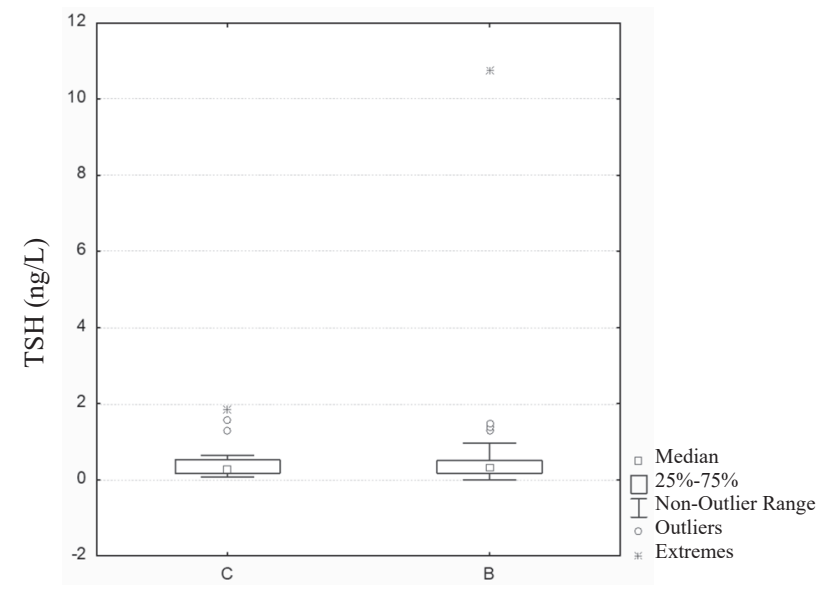

Fig. 2. Comparison of TSH concentration in control group (C) and group of dogs with babesiosis (B)

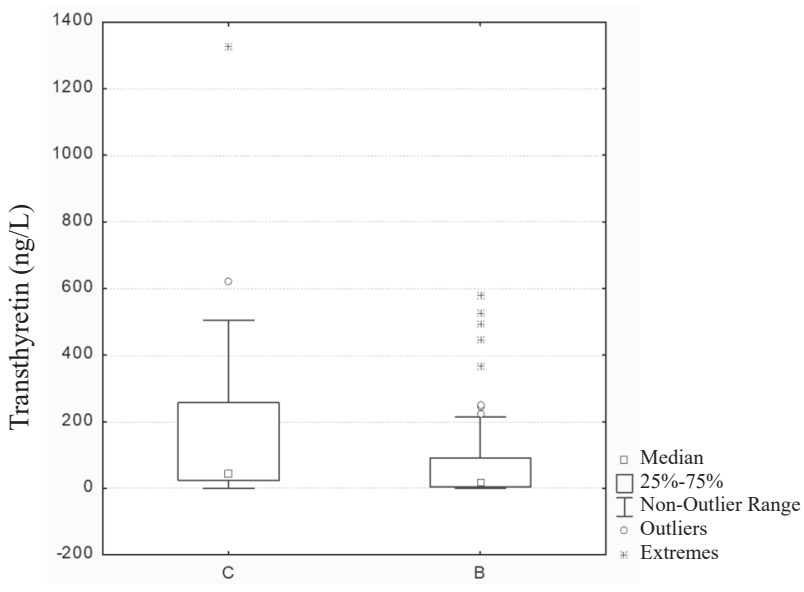

Fig. 3. Comparison of TTR concentration in control group (C) and group of dogs with babesiosis (B) 
N. Kučer et al.: Evaluation of thyroid function abnormalities in sixty dogs naturally infected with Babesia canis

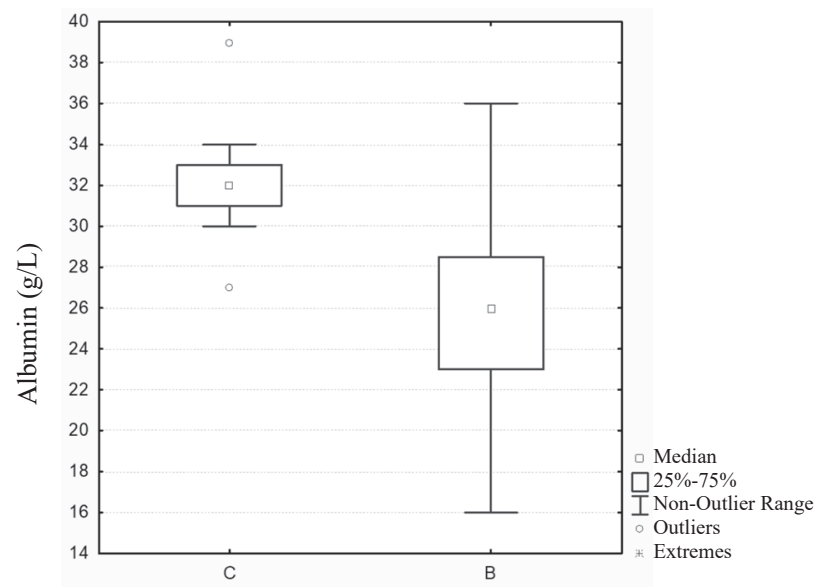

Fig. 4. Comparison of albumin concentration in control group (C) and group of dogs with babesiosis (B)

\section{Discussion}

Patients with nonthyroidal illness syndrome were thought to be euthyroid with multiple alterations in their serum thyroid hormone levels. The current study suggests that these patients may not be euthyroid, but have acquired transient central hypothyroidism. Nonthyroidal illness syndrome is characterised by low serum levels of T3, normal or low serum levels of T4 and normal or low serum levels of TSH. Pathogenetic mechanisms also include the decreased conversion of T4 to T3 in extrathyroidal tissues, and alterations in thyroid hormones binding to serum proteins. These multiple and complex alterations take place in critical illness settings. The mechanism involved is not yet clearly understood (WARNER and BECKETT, 2010).

In this research, a significant statistical difference was observed in the concentrations of thyroxine between dogs suffering from babesiosis and the healthy group of dogs ( $\mathrm{P}$ $=0.0001)$. The significantly reduced concentrations of T4 in the sick dogs indicated the development of nonthyroidal illness syndrome. Similar results were find in the study conducted by ZYNGER et al. (2015)

In contrast to the study mentioned, we did not found any statistically significant difference in TSH concentrations between the groups. The normal level of TSH and the decline in T4 concentrations indicate uncompensated hypothyroidism, while the decline in TTR and albumin concentrations indicates inflammatory response activation.

The complexity of the pathogenesis of NTIS comprises changes in the hypothalamuspituitary axis, altered thyroid hormone binding to proteins, modification of the hormone's 
entry into the tissues, impaired intracellular deiodinal activity, and alteration in thyroid hormone nuclear receptors (WARNER and BECKETT, 2010).

Central hypothyroidism occurs due to a decrease in the hypothalamic TRH secretion. There are numerous reasons for the TRH deficiency in the hypothalamus during NITS, i.e. reduced calorie intake, low concentrations of leptin during starvation, and inflammatory cytokine activation. In fact, the reduction of basal T3 levels reflects the organism's attempt to conserve energy by minimizing catabolism in starvation, stress or critical illness (MYERS ADLER and WARTOFSKY, 2007).

The glucocorticoids may also affect TRH secretion. Large quantities of glucocorticoid in Cushing's disease can suppress the secretion of TSH. In humans it has been proven that high corticosteroids level supress the pituitary response to TRH. In a similar way, stressinduced glucocorticoids provoke suppression of TSH and thus lower the level of T3 and T4 (DE GROOT, 1999).

In central hypothyroidism, serum TSH is often normal (WARNER and BECKETT, 2010). This is confirmed by the results of this research, proving that there is no significant statistical difference between TSH concentrations in the serum of the sick and healthy groups of dogs $(\mathrm{P}<0.05)$. In NTIS, the level of T3 in the pituitary gland is normal due to the increased intrapituitary deiodination of T4 into T3, and the pituitary gland remains euthyroid, while the rest of the body is hypothyroidal so the pituitary gland is not stimulated to TSH secretion. Due to decreased glycolation, TSH bioactivity is further reduced. It is assumed that the hypothalamic function is suppressed in NTIS, which leads to decreased secretion of TRH, and consequently TSH, and in the end of thyroid hormones (DE GROOT, 1999).

Proinflammatory cytokines released locally, in the peripheral tissue, in sepsis, trauma or autoimmune diseases, may also directly affect the pituitary gland and reduce the release of TSH. IL-6 appears to be potentially important in suppression of TSH plasma levels. Also, other cytokines, including TNF- $\alpha$ and interferon- $\gamma$, may have a similar effect (WARNER and BECKETT, 2010). MICHALAKI et al. 2001. observed that T3 in the serum declines soon after abdominal surgery, but before the increase of cytokine IL-6 and TNF- $\alpha$ in the serum, so the authors concluded that the changes in cytokines do not induce the decline of T3 hormones. HERMUS et al. (1992) determined that a continuous infusion of IL-1 in rats caused suppression of TSH, T3 and free T4 hormones, but VAN DER POLL et al. (1997) published a study which demonstrated that the IL-1 blockade failed to prevent the decrease of circulating concentrations of T4, free T4, T3, TSH, or the increase in reverse T3 (rT3). Furthermore, according to VAN DER POLL et al. (1997) TNF neutralisation does not influence the thyroid hormone function in people exposed to endotoxin. It may be concluded that because of its complex network paths, the role of cytokines in NTIS is still insufficiently explored (DE GROTT, 1999). 
Activation and inactivation of thyroid hormones are mediated by the group of three iodothyronine deiodinases. Deiodinase D1, D2 and D3 have a particular tissue distribution and physiological role. D1 and D2 activate T4 by removing the iodine atom from the outer ring 5 'and, by deiodination, form biologically active T3, whereby D3 inactivates T3 and $\mathrm{T} 4$ by removing the iodine atom from the inner ring ( 5 deiodination), thus forming $\mathrm{T} 2$ and biologically inactive reverse T3 (rT3) (WARNER and BECKETT, 2010). The potential role of deiodinases in NTIS-in is still controversial. Extrathyroidal conversion of T4 to $\mathrm{T} 3$ is diminished in illness due to the reduction of D1 activity in hepatic and renal tissues, and D2 activity in skeletal muscle tissues. Increased activity of D3 in skeletal muscle leads to increased production of rT3 and catabolisation of T3 to T2, which may also contribute to low $\mathrm{T} 3$ levels in the circulation. In research on human cells it was found that IL-6 reduces conversion of T4 to T3 by reducing the activity of D1 and D2 deiodinases, and increases D3 deiodinase activity, consequently causing increased inactivation of the thyroid hormone (WAJNER et al., 2011).

Intracellular T3 and T4 concentrations depend not only on the local activity of deiodinases, but also its ability to enter cells. If cellular input is impaired, intracellular deiodination is not satisfactory, which further creates reduced peripheral production of $\mathrm{T} 3$ and potential tissue hypothyroidism. The mechanisms required for thyroid hormones to enter and exit the cells include transport proteins and ATP consumption (WARNER and BECKETT, 2010). Accordingly, in the case of starvation or liver disease, the lack of energy leads to decreased entry of T4 into hepatic cells (SATTAR et al., 2003), but in spite of decreased intake, the transport proteins are not considered responsible for impaired thyroid hormone input during disease (WARNER and BECKETT, 2010).

The activity of the thyroid hormone depends largely on its attachment to the receptors in the nucleus of the cell. The results of the research in current studies indicate changes in the expression of receptors in NTIS, but with contradictory findings. In general, in chronic diseases the expression of receptors increases, while in acute illness it decreases. It is considered that the sudden decline in T3 in the serum, as seen in acute diseases, is most likely caused by either weakened thyroid T3 production (due to central hypothyroidism) and/or as a result of acute phase response and the consequently decreased binding protein synthesis (WARNER and BECKETT, 2010).

In earlier literature it was stated that some endogenous substances similar to free fatty acids (NEFA) may accumulate in plasma during NTIS and inhibit the binding of T4 and T3 to their carriers. The investigations of BRENT and HERSHERMAN (1986) do not support this hypothesis; in their study T4 supplementation in NTIS settings resulted in the normalization of the peripheral concentration of hormones, which would not be possible in the presence of an interfering inhibitor of the binding mechanism (DE GROOT, 1999). However, in sick patients the ability to bind is weakened and it is therefore possible that 
some substances such as medications (e.g. furosemide) compete with thyroid hormones in binding with their carrier proteins which can ultimately lead to reductions in overall $\mathrm{T} 3$ and T4 concentration (WARNER and BECKETT, 2010).

Most circulating T4 is linked to TBG, and in a slightly lower degree on TTR and albumin. The unbounded, free fraction of the $\mathrm{T} 4$ is $<0.1 \%$ of the total T 4 . The concentration of the total T4 in part depends on the concentration of binding proteins (PIECHOTTA et al., 2012). Guided by this hypothesis we have planned to determine whether TTR and albumin concentrations were changed in dogs of babesiosis. Because of the negative proteins of acute phase response, the assumption was that their concentration would fall. The results obtained indicate a significant statistical difference in the concentration of TTR $(\mathrm{P}=0.0406)$ and albumin concentration between healthy and diseased groups of dogs. PIECHOTTA et al. (2012) obtained about the same results, but probably because of the use of the semi-quantitative method they did not get a significant difference for TTR between groups of healthy dogs and dogs with NTIS. Despite this, they received a significant decrease in TTR in dogs with NTIS versus hypothyireotic dogs. This indicates that TTR may be used as a diagnostic marker for identification of NTIS versus hypothyroidism in dogs, but such assumptions have yet to be confirmed.

Furthermore, the emergence of NTIS can also be linked to the reduction of the thyroid hormone carrier concentration, which is a consequence of the activation of acute phase response. Decrease of negative acute-phase proteins, some of which are thyroid hormones carriers, can occur due to low synthesis, increased degradation and migration from intravascular to "third" spaces (JIRASAKULDECH et al., 2000), and for hypoalbuminemia it is considered to be possible due to haemodilution. The reduced albumin synthesis occurs during inflammation, when synthesis of positive acute-phase proteins is intensified, and in liver failure and chronic malnutrition. The increased loss of albumin occurs also in the case of bleeding, protein-losing enteropathy and nephropathy. The redistribution of albumin is part of the inflammation of the vascular system mechanism and involved in peritonitis, pleuritis, and vasculitis or sepsis onset. During aggressive fluid therapy and in diseases that cause fluid retention such as heart disease or oliguric/ anuric renal failure, hypoalbuminemia may arise due to haemodilution (THROOP et al., 2004).

According to the results of our research we have confirmed hypoalbuminemia in canine babesiosis; the same results were given by MAEGRAITH et al. (1957), MALHERBE (1966) and LOBETTI et al. (2000). CAMACHO et al. (2005) who investigated serum protein response and renal failure in $\operatorname{dog}$ infection caused by $B$. anne demonstrated that dogs with azotemia had a significantly lower albumin concentration than those in which the azotemia was not observed. The increased loss of albumin in this 
case is associated with renal failure and albuminuria. APAYDIN and DEDE (2010) also confirmed hypoalbuminemia in sheep infected with B. ovis.

Finally, we concluded that an acute phase response that is manifested in the reduction of albumin and transthyretin concentration in the serum (the T3-and-T4 carriers) certainly contributes to the overall reduction of thyroid hormone concentrations in the dogs infected with B. canis.

Numerous studies confirm strong positive correlations between the low level of thyroid hormone in the blood and the poorer outcome of the critical illness in humans and animals, (MYERS ADLER and WARTOFSKY, 2007; SCHOEMAN et al., 2007). There is a possibility that NITS patients would benefit from thyroid hormone supplementation. However, it is not routinely introduced in treatment and still is controversial whether NTIS represents a protective adaptation of the organism to stress or a maladjusted response to a disease that needs to be corrected (BELLO et al., 2009).

\section{Reference}

AFANDI, B., R. VERA, G. C. SCHUSSLER, M. G. YAP (2000): Concordant decreases of thyroxine and thyroxine binding protein concentrations during sepsis. Metabolism 49, 753-754.

DOI: $10.1053 /$ meta.2000.6239

APAYDIN, B., S. DEDE (2010): Electrophoretic profile of serum protein fractions from sheep naturally infected with Babesia ovis. Rev. Med. Vet. 161, 57-60.

BECK, R., L. VOJTA, V. MRLJAK, A. MARINCULIĆ, A. BECK, T. ŽIVIČNJAK, S. M. CACCIO (2009): Diversity of Babesia and Theileria species in symptomatic and asymptomatic dogs in Croatia. Int. J. Parasitol. 39, 843-848.

DOI: 10.1016/j.ijpara.2008.12.005

BELlO, G., G. PALIANI, M. G. ANNETTA, A. PONTECORVI, M. ANTONELli (2009): Treating nonthyroidal illness syndrome in the critically ill patient: still a matter of controversy. Curr. Drug Targets, 10, 778-787.

DOI: $10.2174 / 138945009788982414$

BIGLER, B. (1976): Thyroxine-binding serum proteins in the cat as compared to dog and man. Schweiz Arch. Tierheilkd. 118, 559-562.

BRENT, G. A., J. M. HERSHMAN (1986): Thyroxine therapy in patients with severe nonthyroidal illnesses and lower serum thyroxine concentration. J. Clin. Endocrinol. Metab. 63, 1-8.

DOI: $10.1210 /$ jcem-63-1-1

CAMACHO, A. T., F. J. GUITIAN, E. PALLAS, J. J. GESTAL, A. S. OLMEDA, H. K. GOETHERT, S. R. TELFORD, A. SPIELMAN (2005): Serum protein response and renal failure in canine Babesia annae infection. Vet. Res. 36, 713-722.

DOI: $10.1051 /$ vetres:2005026 
N. Kučer et al.: Evaluation of thyroid function abnormalities in sixty dogs naturally infected with Babesia canis

CERÓN, J. J., P. D. ECKERSALL, S. M. MARTÍNEZ-SUBIELA (2005): Acute phase proteins in dogs and cats: Current knowledge and future perspectives. Vet. Clin. Pathol. 34, 85-99.

DOI: $10.1111 / j .1939-165 X .2005 . t b 00019 . x$

DE GROOT, L. J. (1999): Dangerous dogmas in medicine: the nonthyroidal illness syndrome. J Clin. Endocrinol. Metab. 84, 151-164.

DOI: $10.1210 /$ jcem.84.1.5364

FARWELL, A. P. (2008): Thyroid hormone therapy is not indicated in the majority of patients with the sick euthyroid syndrome. Endocr. Pract. 14, 1180-1187.

DOI: 10.4158/EP.14.9.1180

FELDMAN, E. C., R. W. NELSON (2003): Hipotireoidism. In: Canine and Feline Endocrinology and Reproduction (Feldman, E. C., R. W. Nelson, Eds.), Saunders Elsevier, St. Luis, pp. 86-88.

HERMUS, R. M., C. G. SWEP, M. J. VAN DER MEER, H. A. ROSS, A. G. SMALS, T. J. BENRAAD, P. W. KLOPPENBORG (1992): Continuous infusion of interleukin-1 beta induces a nonthyroidal illness syndrome in the rat. Endocrinology 131, 2139-2146

DOI: $10.1210 /$ endo.131.5.1425414

JIRASAKULDECH, B., G. C. SCHUSSLER, M. G. YAP, H. DREW, A. JOSEPHSON, J. MICHL (2000): A characteristic serpin cleavage product of thyroxine-binding globulin appears in sepsis sera. J. Clin. Endocrin. Metabol. 85, 3996-3999.

DOI: $10.1210 /$ jcem.85.11.6966

KIŠ, I. (2007): Application of the clinical scoring system in assessing the outcome prognosis of babeziosis in dogs. Faculty of Veterinary Medicine, University of Zagreb, Zagreb. PhD Thesis (in Croatian).

LARSSON, M., T. PETTERSSON, A. CARLSTROM (1985): Thyroid hormone binding in serum of 15 vertebrate species: isolation of thyroxine-binding globulin and prealbumin analogs. Gen. Comp. Endocrinol. 58, 360-375.

DOI: 10.1016/0016-6480(85)90108-X

LOBETTI, R. G., A. J. MÖHR, T. DIPPENAAR, E. MYBURGH (2000): A preliminary study on the serum protein response in canine babesiosis. J. South Afr. Vet. Assoc. 71, 38-42.

DOI: 10.4102 /jsava.v71i1.675

MAEGRAITH, B., H. M. GILLES, K. DEVAKUL (1957): Pathological processes in Babesia canis infections. Z. Tropenmed. Parasit. 8, 485-514.

MALHERBE, W. D. (1966): A clinico-pathological study of Babesia canis infection in dogs. PhD Thesis, University of Pretoria.

MICHALAKI, M., A. G. VAGENAKIS, M. MAKRI, F. KALFARENTZOS, V. KYRIAZOPOULOU (2001): Dissociation of the early decline in serum T(3) concentration and serum IL-6 rise and TNFalpha in nonthyroidal illness syndrome induced by abdominal surgery. J. Clin. Endocrinol. Metab. 86, 4198-4205.

MYERS ADLER, S., L. WARTOFSKY (2007): The nonthyroidal illness syndrome. Endocrinol. Metab. Clin. N. Am. 36, 657-672.

DOI: $10.1016 /$ j.ecl.2007.04.007

Vet. arhiv 89 (1), 55-69, 2019 
N. Kučer et al.: Evaluation of thyroid function abnormalities in sixty dogs naturally infected with Babesia canis

PIECHOTTA, M., R. JENS, M. RICK, M. BEYERBACH, H. O. HOPPEN (2012): Serum transthyretin concentration is decreased in dogs with nonthyroidal illness. Vet. Clin. Pathol. 41, 110-113.

DOI: 10.1111/j.1939-165X.2011.00394.x

SATTAR, A., N. ASIF, M. M. DAWOOD, T. RAFI, Z. REHMAN, M. AAMIR (2003): Euthyroid sick syndrome. J. Pak. Med. Assoc. 53, 1-7.

SCHETTERS, T., J. A. G. M. KLEUSKENS, J. VAN DE CROMMERT, P. W. J. DE LEEUW, A.-L. FINIZIO, A. GORENFLOT (2009): Systemic inflammatory responses in dogs experimentally infected with Babesia canis; a haematological study. Vet. Parasitol. 162, 7-15.

DOI: 10.1016/j.vetpar.2009.02.012

SCHOEMAN, J. P. (2009): Canine babesiosis. Onderstepoort. J. Vet. Res. 76, 59-66.

DOI: $10.4102 /$ ojvr.v76i1.66

SCHOEMAN, J. P., P. REES, M. E. HERRTAGE (2007): Endocrine predictors of mortality in canine babesiosis caused by Babesia canis rossi. Vet. Parasitol. 148, 75-82.

DOI: $10.1016 /$ j.vetpar.2007.06.010

SELANEC, J., M. TORTI, I. ŠMIT, I. MAYER, J. KULEŠ, I. JOVIĆ, V. MRLJAK (2012): Recent insights about the babesiosis of dogs. Vet. stanica 43, 497-505 (in Croatian).

SOLANO-GALLEGO, L, G. BANETH (2011): Babesiosis in dogs and cats - Expanding parasitological and clinical spectra. Vet. Parasitol. 181, 48-60.

DOI: $10.1016 /$ j.vetpar.2011.04.023

THROOP, J. L., M. E. KERL, L. A. COHN (2004): Albumin in Health and Disease: Causes and Treatment of Hypoalbuminemia. Compend. Contin. Educ. 26, 940-949.

VAN DER POLL, T., P. M. JANSEN, W. J. MONTEGUT (1997): Effects of IL-10 on systemic inflammatory responses during sublethal primate endotoxemia. J. Immunol. 158, 1971-1975.

WAJNER, S. M., I. M. GOEMANN, A. L. BUENO, P. R. LARSEN, A. L. MAIA (2011): IL-6 promotes nonthyroidal illness syndrome by blocking thyroxine activation while promoting thyroid hormone inactivation in human cells. J. Clin. Invest. 121, 1834-1845.

DOI: $10.1172 / J C I 44678$

WARNER, M. H., BECKETT, G. J. (2010): Mechanisms behind the nonthyroidal illness syndrome: an update. J. Endocrynol. 205, 1-13.

DOI: $10.1677 /$ JOE-09-0412

ZYGNER, W., O. GÓJSKA-ZYGNER, P. BASKA, E. DLUGOSZ (2015): Low T3 syndrome in canine babesiosis associated with increased serum IL-6 concentration and azotaemia. Vet. Parasitol. 211, 23-27.

DOI: $10.1016 /$ j.vetpar.2015.04.023

Received: 19 November 2017

Accepted: 31 January 2019 


\section{KUČER, N., H. MARIN, J. GOTIĆ, J. KULEŠ, J. TRŠAN, F. KAJIN, R. BARIĆ RAFAJ: Procjena poremećaja funkcije štitnjače u pasa oboljelih od babezioze. Vet. arhiv 89, 55-69, 2019.}

\section{SAŽETAK}

Babezioza je česta bolest pasa. Obilježava je razaranje eritrocita te upalni odgovor praćen porastom serumske koncentracije pozitivnih akutnofaznih proteina i padom serumske koncentracije negativnih akutnofaznih proteina. Neki od negativnih akutnofaznih proteina imaju funkciju nosača hormona štitnjače, stoga je cilj istraživanja bio utvrđivanje sindroma netireoidne upalne bolesti kod pasa oboljelih od babezioze. $\mathrm{U}$ istraživanje je bilo uključeno 60 pasa kod kojih je u eritrocitima potvrđena prisutnost parazita $B$. canis te 26 zdravih pasa. Imunoenzimskim testom u serumu pasa izmjerene su koncentracije tiroksina, tirotropina i transtiretina, a koncentracija albumina izmjerena je spektrofotometrijskom metodom. Statističkom obradom podataka dokazano je statistički znakovito smanjenje koncentracije tiroksina, transtiretina i albumina u serumu pasa oboljelih od babezioze, dok se koncentracija tirotropina nije znakovito razlikovala u odnosu na kontrolnu skupinu. Dobiveni rezultati upućuju na prisutnost sindroma netireoidne bolesti, pri čemu je pad koncentracije albumina i transtiretina vjerojatno jedan od mehanizama nastanka ovoga sindroma kod babezioze pasa.

Ključne riječi: pas; babezioza; sindrom netireoidne bolesti; transtiretin 
